\title{
De las anotaciones preventivas de las demandas
}

\author{
por el Doctor JOSE MERINO REYNA, \\ Vocal de la Corte Superior de Lima, \\ Catedrático de Derecho Procesal Civil en la Universidad Católica
}

Muchos abogados se lamentan que un usa indiscriminado de la facultad que el inciso $8^{\circ}$ del art. 1042 del C. C. concede a los señores Jueces, forme un ambiente de vacilación $y$ origine indudables perjuicios para la contratación $y$, en general, para el crédito territorial.

Cuando el Código, en la disposición citada, establece que son inscribibles en el Registro del Departamento o Provincia de la ubicación del inmueble "las demandas que a juicio del Juez se refieran a actos inscribibles", no quiere decir, sin duda alguna, que todos los pedidos de inscrip-ción hayan de ser amparados sin prueba instrumental que sustente la. petición.

Empero, en la práctica, se observa una actitud extremadamente generosa para la cautela de los derechos que se demandan, muchos de los cuales van a ser materia de una sentencia de carácter constitutivo $y$ muchos más no son por cierto derechos reales.

Cuando el C. C. confirió a la Corte Suprema la facultad de aprobar el Reglamento General de las Inscripciones, y lo hizo por el mandato del art. 1039 del C. C., el Tribunal Supremo produjo su acuerdo por el informe del señor don Ánselmo V. Barreto, quien no formuló una sola observación de fondo, ni siquiera de detalle, al trabajo de la Comisión.

La Ley de 2 de enero de 1888, sobre Registro de la Propiedad Inmueble, decía que "puede pedir la anotación preventiva de sus respectivos derechos en el correspondiente registro:... I $1^{9-E I}$ que demanda judicialmente la propiedad de bienes inmuebles o la constitución, declaración, modificación o extinción de cualquier derecho real'. Y más adelante, en el art. 103, indicaba que para este caso solo podía extenderse anota. ción preventiva con mandato judicial $y$ en virtud de documento que sea. bastante a juicio del Juez de la causa..., etc.

No se encuentra en la legislación que sustituyó este Reglamento. las dos notas clarísimas apuntadas: el carácter de derecho real y el documento suficiente a juicio del Juez. 
Bien se aprecia que no se podría, en la evolución de la jurisprudencia, restringir las anotaciones a la constitución, modificación o extinción de un derecho real inmobiliario, pues la medida cautelar que la anotación supone, también se dicta para amparar pretensiones de un derecho personal, cuando las acciones personales producen como consecuencia una modificación de una inscripción en el Registro de la Propiedad. También se aprecia que el documento bastante, de que hablaba la legislación anterior, no puede tener los exigentes caracteres del art. 227 del C. de P. C., pues si el actor tuviera documento de tal tipo, pediría el embargo y no la anotación de la litis. Pero, en países de avanzada cultura jurídica se recomienda que la jurisprudencia adopte una posición ecléctica: ni la liberalidad de conceder toda anotación por el solo hecho de solicitarla, y sin documento alguno, pues llevaría al abuso; y tampoco la exigencia de instrumento en los términos del art. 227 citados, pues haría inocua la medida, que en último análisis tiene como propósito una publicidad de la litis a fin de que el tercer adquirente no pueda alegar ignorancia y soporte, $\in \mathrm{n}$ consecuencia, los efectos de la sentencia.

Quizá si la razón de la excesiva liberalidad en la concesión de esta medida cautelar sea la de estimar que la anotación de la demanda no perjudica al demandado desde que no le impide la libre disposición de sus bienes. Pero esto no pasa de ser una declaración lírica, pues en la práctica las efectos de la anotación se perciben con tanto o más rigor que los efectos de un embargo, que tampoco tendría por qué impedir la trasmisión del bien.

En efecto: nadie contrata respeto a un inmueble en el que incida una anotación de demanda, por el rigor del Reglamento actual de los Registros, cuyo art. 86 previene: "Los bienes inmuebles y los derechos inscribibles anotados, pueden ser enajenados, pero sin perjuicio del derecho: de la persona a cuyo favor se haya extendido la anotación".

No es por tanto cierto que si la traslación de dominio respecto de un bien que soporta la cnotación de una demanda, se produce por escritura de adjudicación en venta judicial, el adquirente en remate público adquiera bien y sin peligro. El imperio del art. 86 permitiría una acción reivindicatoria de la que el subastador no se percibe como podría escapar.

A esto se agrega que la inscripción no puede, como el embargo, ser levantado bajo de fianza, ni tampoco podría substituirse la anotación con otra medida precautoria, porque éllo dependería de la voluntad del demandante el que, obviamente no ha de acceder. Tampoco podría prosperar una tercería la que solo puede incidir allí donde haya embargo, de suerte que si la Corte Superior confirma el cuto que desestima la oposición a la inscripción, el demandado debe esperar el final de un dilatado juicio, por lo general ordinario, para sacudirse del peso de una anotación que ha de haberle causado incontables perjuicios.

Todavía yo encuentro que, por razones de mero procedimiento, algunas veces el problema se complica. No es raro ver que se declara fundada la queja por denegatoria del recurso de nulidad que ha resuelto el incidente o la incidencia de la inscripción. $Y$ surge este razonamiento. Si la inscripción no puede ser en ningún caso más que un embargo, ¿cómo 
el Tribunal Supremo, tan celoso para no conocer de los embargos, podría incidentalmente tratar una cuestión de inscripción? Formalmente el recurso sería improcedente y la solución no se conciliaría con la circunstancia de haber hecho lugar a la queja. Se trataría quizó́ el problema, sobre el fondo de la cuestión: si la demanda era o no inscribible, y en todo caso se resiente algo la estructura jurídica de esta argumentación.

No es todo: en la práctica judicial, se utiliza como sinónimos, por lo menos en la realidad de las cosas, los términos anotación e inscripción, existiendo diferencia, pues se aprecia que lo primero tiene sentido y carácter de provisoriedad y lo segundo de definitivo. Más todavía, cuando el art. 1042, inciso $8^{\circ}$ llama inscripción, $y$ el art. siguiente, 1043, al remitir el asunto al Reglamento, lo encasilla en el art. 79 para el cual esa inscripción no es sino una anotación preventiva, así fuere por la naturaleza de las sentencias que ponen tin a los procesos en los cuales se pide Y obtiene la medida que criticamos.

Completa el cuadro de la dificultad la consideración de que el C. C. considera explícitamente que la anotación de la demanda constituye un gravamen real. El art. 1049 se refiere a la renovación de las inscripciones de las hipotecas " $y$ de los demós gravámenes indicados en los incisos $5^{\circ}$ a $8^{\circ}$ del art. 1042". Este último artículo contempla en su inciso $8^{\circ}$ las demandas. Se equipara así la anotación de un embargo con la anotación de la litis.

En conclusión: cuando se anota una demanda se estaría constituyendo un "gravamen real".

Sin la pretensión de marcar rumbos a magistrados judiciales y abogados, sino simplemente como una guía auxiliar de la cátedra que, hace cinco años, regentamos en la Pontificia Universidad Católica, bueno es llamar la atención de los alumnos sobre la trascendencia de la anotación de la litis, tan fácilmente concedida, que suscita tantas discusiones $y$ acarrea tantos perjuicios. 